\title{
ACERCA DE LAS REDONDILLAS DE SOR JUANA INES DE LA CRUZ
}

$\mathbf{P} \mathbf{R}$

CLEM E N T I N A DIAZ Y DE O V A N D O

I A composición más popular de Sor Juana es, seguramente, la redondilla que lleva por comentario: Arguye de inconsequentes el gusto $y$ la censura de los hombres, que en las mujeres acusan lo que causan.

Esta formidable requisitoria al varón ¿carece de influencias extrañas a la inspiración de la "Décima Musa"?

Por las relaciones que pueden establecerse entre la redondilla y un romance caballeresco de autor anónimo intitulado $E l$ maldiciente, asegurariamos lo contrario.

Ya los eruditos han estudiado el sedimento que Góngora y Quevedo dejan en la obra de Sor Juana; y así, como éstos, sus excelsos modelos, a pesar del barroco decir y de las conceptuosas imágenes, no desdeñan componer romances - los artísticos o nuevos- también nuestra monja recurre a tan encantadoras canciones populares.

Poetisa de exquisita y verdadera sensibilidad, no obstante el juicio adverso de fray Benito Jerónimo Feijóo: "diré que lo que menos tuvo 
fué talento poético aunque es lo que más se celebra", 1 no podia sustraerse a la inefable belleza romancera.

Los romances, desde que los hispanos llegan en plan conquistador y colonizador a las recién descubiertas tierras, se recuerdan y se recitan en todas las ocasiones. $Y$, durante los siglos $x v i$ y $x$ vI, los de su auge en España, arriban sin interrupción a las Indias, puesto que representan el eco vivo de la patria. Es tanta su aceptación que al menospreciarse por los poetas italianizantes, se prolonga en las nuevas colonias la discusión y defensa del metro nacional, iniciada vigorosamente en la Península por Cristóbal de Castillejo y concluida en definitiva por Lope de Vega.

El conquistador del Nuevo Reino de Granada, Gonzalo Jiménez de Quesada, según referencia de Juan Castellanos en sus Elegías de varones ilustres de las Indias, era, junto con sus caballeros decidido defensor del octosilabo, por su arraigo netamente español:

$$
\begin{aligned}
& \text { y el porfió conmigo muchas veces } \\
& \text { ser los metros antiguos castellanos } \\
& \text { los propios y adaptados a la lengua } \\
& \text { por ser bijos nacidos de su vientre... }
\end{aligned}
$$

y en pláticas que se animaban al debatirse este asunto, se recurría a los romances primitivos para remachar la defensa. 1

En la centuria del Xvir en que vive Sor Juana, magüer la real cédula de Felipe II dada en 1542 impidiendo su entrada a los Virreinatos y Capitanías, y de la perjudicial infiltración erudita en la poesía, sigue el éxito de los romances en todos los dominios ibéricos.

Los códices coloniales que ahora van desempolvándose, nos muestran cómo se les conoce en las diferentes posesiones ultramarinas y cómo interfieren sus versos en las creaciones romancescas de factura autóctona. Además, conforme avanza el estudio del Romancero en América, aparecen innúmeros romances conservados por la tradición oral, aunque modificados muchos de ellos por su contextura realista $y$, en parte, según opinión de don Vicente T. Mendoza, por el Santo Oficio, que al incinerar los Romanceros contribuye a que se rehagan: perdida la escritura, el gusto del memorizador metamorfosea los renglones.

En metro de romance se notician en la Colonia los cambios de Virreyes, se describen las fiestas profanas y religiosas; las honras fúnebres, por pág. 14.

1 Citado en Semblanza de Sor Juana, Ermilo Abreu Gómez, Mérico, 1938.

1 Romancero. Ismael Moya, Buenos Aires, 1941, pága. 108-9. 
demás suntuosas, de los vasallos indianos a su fenecido rey; y regocijada o irónicamente, se aluden las costumbres.

Si los romances se aprenden, se rehacen y constantemente se repiten; si con ellos se dan informes del cotidiano vivir colonial i no es presumible que sean conocidos de la célebre jerónima y puedan advertirse en sus redondillas?

El romance El maldiciente está consignado en el Romancero general de la "Biblioteca de Autores Españoles". 1 Don Agustín Durán, el erudito compilador, anota al pie de la composición el texto del cual está tomado: Romancero general. Este dato nos hizo suponer que seria el publicado en 1604. Durán, en una compilación antecedente, Romancero de romances caballerescos e históricos anteriores al siglo $X V I I I,{ }^{2}$ señala más explícitamente las fuentes que sirvieron para la formación de dicho Romancero, que incluye el romance mencionado. Entre los textos citados se encuentra el de 1604: Romancero general en que se contienen todos los romances que andan impresos, etc., 4\%, Madrid, 1604 ; de aquí tomó Durán el romance $E l$ maldiciente, pues todos los romances que se cantaban o se habían publicado en las diferentes "Flores", "Rosas" o "Silvas" fueron consignados en esta magnífica colección.

Que el precitado romance provenga de este Romancero, indica que para aquella fecha era muy sabido; tal ocurría con los romances viejos o primitivos, grupo en el cual Durán lo cataloga.

Su notorio conocimiento coincide, asimismo, con la época en que los peninsulares, gustadores todos del romance, se desplazan en grandes núcleos a América; y más de alguno, oculto en su bagaje por temor a la Inquisición, traería como un tesoro este Romancero.

En los volúmenes de la biblioteca de Sor Juana, de los que da un índice, aunque no completo, de títulos y autores, Ermilo Abreu Gómez, no se menciona ninguno de los romanceros publicados a príncipios del siglo xvil y que fueron: Romancero de 1600 , el famoso Romancero general de 1604, Romancero general ahora nuevamente añadido y enmendado por Pedro Flores, 49, Madrid, 1614, "reimpresión del anterior"; Segunda parte del Romancero general y Flor de diversa poesía recopilada por Mignel de Madrigal, 49, Valladolid, 1605 ("la boga del Romancero general abarca de 1600 a 1614"); sin embargo, si figuran en la librería autores considerados heréticos, tales como Lutero y Erasmo, es imposible

1 Madrid, 1851, pág. 182.

2 Madrid, Imprenta Eusebio Aguado, 1832. 
que Sor Juana no hubiese conocido cualquiera de estos romanceros tan gustados y leídos, ya que contenían la más bella poesía y eran los manuales del saber popular. Ahora bien, supongamos que ninguno de los romanceros, por la vigilancia inquisitorial, llegase a sus manos; esto no invalida nuestro dicho, pues el tantas veces mencionado romance debió escucharlo, junto con otros, ya que los romances acudían insensiblemente a la memoria de los recién llegados y los repetían los aquí avecindados. $Y$ acaso el mismo padre de la poetisa, don José de Asbaje y Vargas Machuca, venido de la Península, gustaria de cantar los viejos versos solariegos; pues el que un español no recitara estas "pequeñas alhajas y dijes familiares", como atinadamente los llama Menéndez Pidal, equivalía, aunque parezca hiperbólico, a no rezar el Padrenuestro.

Tan sabidos y repetidos eran los romances que no sólo se cantaban de continuo, sino que sus voces y conceptos resonaban en los Corrales, pues fueron venero nutricio de las comedias de Juan de la Cueva y Lope de Vega y hasta $E l$ Quijote de la Mancha debe, a ellos, el tema de su elaboración.

E1 mexicano Juan Ruiz de Alarcón, pretendiente en España durante el mayor auge del género romanceril, no es a él insensible. En su comedia Todo es ventura, el gracioso, personaje dignificado por Alarcón, expresa sentimientos que pueden semejarse a los de El maldiciente. Don Juan, cuya nobleza trasciende a su obra, destaca siempre las cualidades femeninas, y si el romance había hecho tan admirable defensa ¿por qué no aprovechar lo tan bien fundamentado si es su propia manera de pensar? Así lo dice con gran ironía por boca del gracioso:

La murmuración afean.

y están siempre murmurando:

$y$ injurian a quien desean.

¿Qué es lo que más condenamos

en las mujeres? ¿El ser

de inconstance parecer?

Nosotros las enseñamos:

que el hombre que llega a estar

del ciego dios más herido.

no deja de sex perdido

por el troppo variar.

¿Tener al dinero amor?

Es cosa de muy buen gusto,

o tire nna piedra el justo.

que no incurre en este ertor.

¿Ser fáciles? ¿Qué han de bacer 


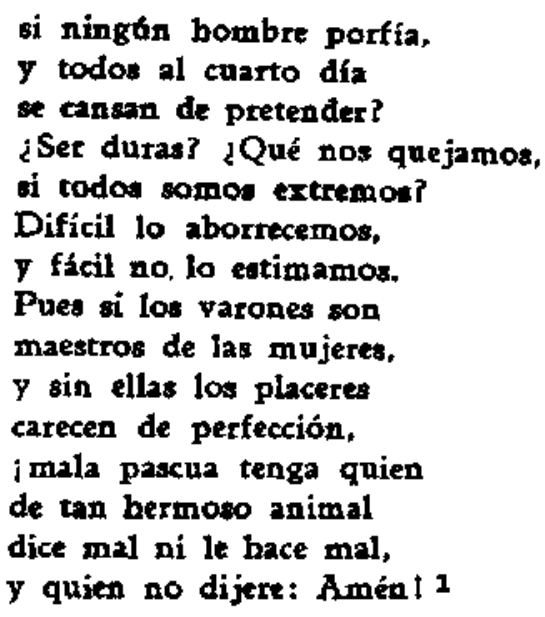

Según el ilustre sorjuanista Manuel Touș̣aint, Sor Juana conoció e imitó la obra de Alarcón; ¿podemos por ello derivar la redonditla de la comedia antes mencionada?

No lo creemos, primeramente por las razones anteriores $y$ después por las analogias asaz claras que hay entre el romance y la redondilla, cuyo tópico común es el insistir masculino para el logro de sus propósitos y que en Ruiz de Alarcón no aparece.

Entre lo dicho por el gracioso Tristán, y to sostenido por Sor Juana, existen sólo los nexos de la natural semejanza que proviene de la referencia al mismo asunto, por dos autores tratado. Sor Juana encontró en los versos alarconianos la repetición de un tema que ya conocía.

A continuación establecemos los paralelos entre El maldiciente y la redondilla. El romance principia de este modo:

Ese conde Cabreruelo. con el rey come a la mesa, toh cuén mal que se abaldona

a toda mujer ajenal

Apuesta que no hay ninguna,

ived coín mal pensada apuesta!,

si le eacucha dos razonee

que de amores no la venza.

Como el amor atrevidas,

como la fortuna ciegas.

como el honor peligrosas,

1 Comedias de Juan Ruiz de Alarcón, "Biblioteca de Autores Espaholes", Rivadeneyra, tomo 20 , págs. 133.4 . 
como la fortuna inciertas, asi jura que son todas:

iFalsa jura!, \injusta tema!

La desmedida jactancia masculina, manifiesta en las afirmaciones del conde, obliga a una mujer a contestar el insulto, aduciendo para ello sensatas razones: los hombres son los únicos responsables de los yerros femeninos:

La reina que tal escucha

dió sañuda tal respuesta:

Traidores hombres del mundo

han hecho traidoras hembras,

delloa aprendieron culpas,

si culpas cometen ellas...

¿No está contenido el pensamiento del romance en la reconvención de Sor Juana? Oigamos los argumentos de la monja, que comienza calificando con preciso adjetivo, pues otro no merece quien ilógicamente se espanta de su propia obra, con gran agrado y constancia realizada:

Hombres necios que acusáis

a la mujer sin razón,

sin ver que sois la ocasión

de lo thimo que culpáis:

si con ansia sin igual

molicitáis su deadén;

¿por qué quertis que obxen bien.

à las incitáis al mal?

Combatis an resistencia,

y luego con gravedad

decis que fué liviandad.

10 que hizo la inteligencia.

Parecer quiere el denuedo

de vuestro parecer loco

al niño, que pone el coco,

$y$ luego le tiene miedo.

Con el faror y al desdén

tenéis condición igual.

quejándoos, si os tretan mal.

burlindoos, si os quiere bien. 
Opinión ninguna gana. pues la que mis se recats. si no os admite, es ingrata. y si os admite, es liviana.

Siempre tan necios andáis. que con designal nivel a una culpsis por cruel. Y a otra por fácil culpáis...

De la diligencia, tesón y métodos que emplean los hombres para hacer a su semejanza a las mujeres, y dejarlas después, inermes ante duras e impertinentes críticas, el romance había dicho con antelación:

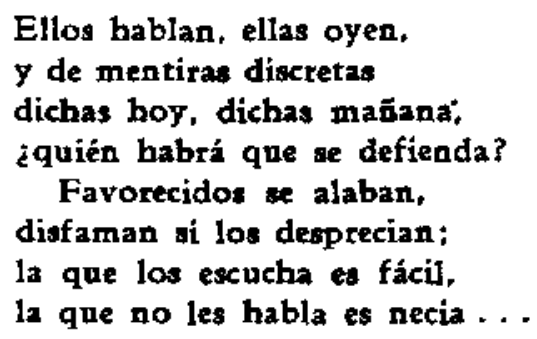

y confirmando la experiencia del refrán "el que persevera alcanza", el premio de la insistencia siempre se obtiene:

Muchas quejas, muchos dones.

¿qué mucho que a ellas prendan!

Ejemplo ea la piedra dura

que agua continua la mella.

Tanto la reina del romance como Sor Juana Inés se encuentran perplejas por la figura femenina, no humana desde luego, que se ha forjado el "mezquino amador". La reina deduce:

-Todas malas no es posible,

ni es posible todas buenas:

yerbas hay que dan la vida,

y quitan 12 vida yerbas...

Y Sor Juana, con gran enojo:

¿Pues cómo ha de entar templada

la que vuestro amor pretende.

si la que es ingrata ofende

Y la que es fácil enfada? 
El romance da otra razón más en defensa de la mujer: hados terribles y maléficos - concepción que rige el amor medieval- marcan su destino y explican el por qué de su conducta:

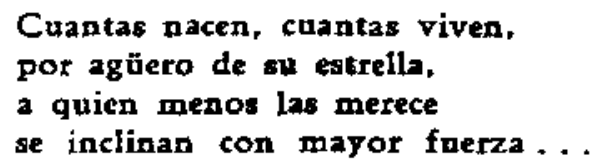

Sor Juana misma, a pesar del intelectualismo del que raras veces prescinde, nos descubre en sus sonetos su corazón de mujer lacerado por grandes desdichas que no merece quien las causa y que, sin embargo, a él la inclinan. Así el soneto que dice:

¿Vea de dolor y angustio el alma llena,

de tan fieros tormentos lastimada.

$y$ entre las vivas llamas abrasada

juzgarme por indigna de su pena? ...

- más claramente en este otro:

a quien mís me desciora, el alma of rezco;

a quien me of rece víctimas, desdoro;

desprecio al que entiquece mi decoro

$y$ al que te bace desprecios enriquezco...

Con gran moderación la reina ha expuesto sus alegatos; en cambio Sor Juana se impacienta tanto por la necedad varonil, que no disimula su alegría cuando se les desprecia. Más adelante, vuelve a insistir en la discordancia entre el sentimiento y la actuación que únicamente conducen a los impugnadores a fundamentar sin razones:

\footnotetext{
Dejad de solicitar,

y después con más razón, acuzaréis la ficción

de la que os fuere a rogar...
}

$\mathbf{Y}$ termina deshaciendo el argüir infamante con armas irrebatibles:

Bien con muchas armea fundo

que lidia vaestra arrogancia.

que en promeas e inatancia

juntáia diablo, carne $y$ mundo. 
El romance y la redondilla, con sus opiniones afines sobre la asiduidad y falsía de los varones, son la respuesta a las torturantes condiciones ambientales, más sensibles aún, para aquella de extraordinario talento y saber :

\section{a que sólo me diste entendimiento porque fuese mi daño más crecido...}

Las letras españolas reproducen la impresión masculina con respecto a la fémina; alguna vez el delicioso tunante Arcipreste de Hita y Lope de Vega guardan una actitud sincera consigo mismos, tal como lo desea Sor Juana :

\section{Queredlas cual las hackis \\ o hacedias cual las buscáis ...}

actitud consonante a su "vitalismo" y al temperamento hispánico del que son fieles exponentes; sólo que el comportamiento de estos dos poetas se pierde en la balumba de dicterios que llenan las obras literarias.

En América, las mujeres de comienzos del xvil tampoco salen bien libradas. Mateo Rosas de Oquendo -algo más pícaro que buen poeta-, durante su estancia en el Perú, traza su semblanza: saben de engaños y fingen tener - pues no tienen- diferentes maneras de ganarse decorosa. mente el sustento. En 1612 (?) está en Nueva España y, refiriéndose a nuestras abuelas, afirma que gustan en demasía del juego de albures, e incansablemente indagan la posición económica del galắn, pues aquí:

$$
\begin{aligned}
& \text { lo que no alcanza Amor. } \\
& \text { todo el interés } 10 \text { alcanza ... }
\end{aligned}
$$

Por estos motivos, Sor Juana, la capacitada, emprende con poderoso alarde femeníno la rebelión contra las limitaciones que implica el tritunfo de la diligencia:

$$
\begin{aligned}
& \text { para pretendida Tais, } \\
& \text { y en } 12 \text { posesión Lucrecia... }
\end{aligned}
$$

y se identifica plenamente con el romance que, como trasunto del pensamiènto popular, apoya siempre a la mujer; y asi lo reitera El maldiciente:

1 Capitulos de literatura española. Alfonso Reyes. La Casa de España en México, 1939, pág. 52. 


\author{
Enmendaos, amigo conde. \\ $y$ de boy miss las damas sean \\ vuestra paz, no vuestra guerra; \\ levantad la parte humilde \\ que et bazaña de alta empresa: \\ todo: de mujer nacimos, \\ volvamos todos por ellas.
}

\title{
BI B L I O GRA F I A
}

AbreU GÓMEZ, ERMILo. Semblanza de Sot Juana. México, 1938.

- Bibliografía y biblioteca de Sor Juana. Bibliografias Mexicanas, MCMXXXIV.

Comedias de Juan Ruiz de Alarcón. Biblioteca de Autores Españoles. Madtid, 1852. tomo 20.

Romancero. Ismael Moya. Buenos Aires, 1941.

Romancero gemeral. Biblioteca de Autores Españoles. Madrid, 1851.

Romencero de romancet cabalteretcos e bistóricos anteriores al siglo XVIII. Agustin Darán. Madrid, 1832, tomo I.

Toussaint, Mxnuei. Sor Juana Inés de la Cruz. Clásicos Mexicanos, México, 1928. 